\title{
Diversidade e potencial zoonótico de parasitos de Didelphis albiventris Lund, 1841 (Marsupialia: Didelphidae)*
}

\author{
GERTRUD MÜLLER ANTUNES
}

\author{
J oão Guilherme Werner Brum (Orientador - UFRGS)
}

Banca: Carlos James Scaini (FURG), Élvia Elena Vianna (UCPel), José Maria Wiest (UFRGS)

Didelphis albiventris, gambá-de-orelha-branca, é um marsupial de hábitos crepusculares e noturnos que se alimenta de frutos, insetos, pequenos répteis e anfíbios, filhotes de aves e pequenos mamíferos. Com a destruição de seu "habitat" natural devido às queimadas e desmatamentos, esses animais têm-se aproximado, cada vez mais, das regiões peridomiciliar e domiciliar, onde procuram abrigo e alimentos. Com o objetivo de conhecer a diversidade de parasitos de $D$. albiventris e relatar os que apresentam potencial zoonótico, foram examinados 30 exemplares desta espécie, através de necropsia, para coleta de ectoparasitos da superfície externa do corpo e helmintos dos órgãos e conteúdos estomacal e intestinal. Os sifonápteros foram removidos da superfície externa dos animais, conservados em álcool etílico a $70^{\circ} \mathrm{GL}$, clarificados em líquido de Nesbitt, desidratados em etanol, diafanizados em creosoto de Faya e montados em lâminas com bálsamo do Canadá para identificação. Os carrapatos foram removidos da superfície externa dos animais, conservados em álcool etílico a $70^{\circ} \mathrm{GL}$ e identificados ao estereomicroscópio, segundo chaves específicas de Aragão \& Fonseca (1961) e Guimarães et al. (2001). Os helmintos foram recolhidos com auxílio de estiletes e pinças, clarificados em lactofenol e montados entre lâminas e lamínulas com bálsamo do Canadá para identificação ao microscópio. Do total de animais examinados, $70 \%$ estavam infestados com pulgas das espécies Polygenis (Neopolygenis) atopus, Polygenis (Polygenis) rimatus, Polygenis (Polygenis) roberti roberti, Polygenis (Polygenis) sp., Craneopsylla minerva minerva e Ctenocephalides felis felis, todas essas registradas pela primeira vez sobre D. albiventris e, exceto $C$. felis felis, são também registradas pela primeira vez no estado do Rio Grande do Sul. Carrapatos foram encontrados em 43,33\% dos animais examinados, representados pelas espécies Ixodes loricatus, Amblyomma aureolatum e Amblyomma sp, sendo A. aureolatum registrado pela primeira vez parasitando D. albiventris no Brasil. Os helmintos encontrados foram: Filo Nematoda - Capillaria spp. (esôfago, traquéia, faringe e pulmão), Didelphostrongylus hayesi (pulmão), Turgida turgida (estômago), Gnathostoma sp. (estômago e fígado), Travassostrongylus orloffi, Viannaia hamata e Trichuris minuta no intestino delgado e Trichuris didelphis, Cruzia tentaculata e Aspidodera raillieti no intestino grosso; Classe Trematoda - Echinostoma revolutum, Plagiorchis didelphidis, Rhopalias coronatus, R. baculifer, Brachylaema migrans e Didelphodiplostomum variabile, todos no intestino delgado; Classe Cestoda - exemplares da família Diphyllobotriidae, no intestino delgado; e Filo Acanthocephala - Hamanniella microcephala e Centrorhynchus sp., ambos no intestino delgado. Dos helmintos encontrados, os que apresentam potencial zoonótico segundo a literatura são T. turgida, Gnathostoma sp., Capillaria spp., B. migrans, E. revolutum e Família Diphyllobotriidae. Além disso, os sifonápteros e ixodídeos encontrados são potenciais vetores de patógenos que infectam humanos. D. albiventris, portanto, apresenta grande diversidade parasitária, incluindo espécies que podem potencialmente atingir o homem, alertando para a importância destes marsupiais na disseminação de doenças entre animais e humanos.

Descritores: Didelphis albiventris, Siphonaptera, Ixodidae, helmintos, Marsupialia, Didelphidae, zoonoses. 


\title{
Diversity and zoonotic potential of Didelphis albiventris Lund, 1841 (Marsupialia: Didelphidae) parasites ${ }^{* *}$
}

\author{
GERTRUD MÜLLER ANTUNES
}

\author{
J oão Guilherme Werner Brum (Adviser - UFRGS)
}

Committee: Carlos James Scaini (FURG), Élvia Elena Vianna (UCPel), José Maria Wiest (UFRGS)

Diversity and zoonotic potential of Didelphis albiventris' parasites. Didelphis albiventris, white-eared-opossum, is a marsupial with crepuscular and nocturnal habits, which feeds with fruits, insects, small reptiles and amphibians, bird's nestling and small mammals. With the destruction of their natural habitat due to burns and deforestation, these animals are getting each time closer to human habitations, where they look for protection and food. With the intuit of knowing the parasites diversity of Didelphis albiventris and report which of these has zoonotic potential, 30 specimens of Didelphis albiventris, which were necropsied and had their organs and intestinal and stomachal contents analyzed for collection of endo and ectoparasites. The siphonapters were removed from the external surface of the animals, conserved in ethylic alcohol $70^{\circ} \mathrm{GL}$, clarified in Nesbitt liquid, dehydrated in ethanol, diaphanized in Faya creosote and mounted on slides with Canada balsam for identification. The ticks were removed from the external surface of the animals, conserved in ethylic alcohol $70^{\circ} \mathrm{GL}$ and identified under stereomicroscope, according specific keys of Aragão \& Fonseca (1961a) and Guimarães et al. (2001). The helminthes were removed with help of tongs, clarified in lacto phenol and mounted in slides with Canada balsam for identification under microscope. From the total of examined animals, $70 \%$ were infested with the fleas Polygenis (Neopolygenis) atopus, Polygenis (Polygenis) rimatus, Polygenis (Polygenis) roberti roberti, Polygenis (Polygenis) sp., Craneopsylla minerva minerva and Ctenocephalides felis felis, all these registered for the first time over D. albiventris and, except for $C$. f. felis, are also registered for the first time in the State of RS. Ticks were found in $43.33 \%$ of the animals examined, represented by the species Ixodes loricatus, Amblyomma aureolatum and Amblyomma sp, being A. aureolatum registered for the first time parasitizing D. albiventris in RS and in Brazil. The helminthes found were: Phyllum Nematoda - Capillaria spp. (esophagus, trachea, pharynx and lung), Didelphostrongylus hayesi (lung), Turgida turgida (stomach), Gnathostoma sp. (stomach and liver), Travassostrongylus orloffi, Viannaia hamata and Trichuris minuta in small intestine and Trichuris didelphis, Cruzia tentaculata and Aspidodera raillieti in large intestine; Class Trematoda - Echinostoma revolutum, Plagiorchis didelphidis, Rhopalias coronatus, R. baculifer, Brachylaema migrans and Didelphodiplostomum variabile, all in small intestine; Class Cestoda - specimens of Diphyllobotriidae family, in small intestine; and Phyllum Acanthocephala Hamanniella microcephala and Centrorhynchus sp., both in small intestine. From these, the ones which has zoonotic potential, according to the literature are T. turgida, Gnathostoma sp., Capillaria spp., B. migrans, E. revolutum and Diphyllobotriidae family. The siphonapters and ixodideans found in D. albiventris are potential vectors of pathogens which infect humans. Didelphis albiventris, therefore, has a great diversity of helminthes, including species which can potentially affect humans, alerting to the importance of these marsupials in the dissemination of diseases among animals and humans.

Key words: Didelphis albiventris, Siphonaptera, Ixodidae, helminthes, Marsupialia, Didelphidae, zoonosis.

\footnotetext{
**Doctoral Dissertation \#51 (Field: Parasitology). 224p. Graduate Program in Veterinary Sciences [www.ufrgs.br/ppgcv], Faculdade de Veterinária, Universidade Federal do Rio Grande do Sul (UFRGS), Porto Alegre/Brazil. CORRESPONDENCE: G.M. Antunes [gertruda@ufpel.tche.br].
} 